\title{
Joeropsidae from Bora Bora and Moorea, Society Islands, with descriptions of four new species (Isopoda: Asellota)
}

\author{
Hans-Georg Müller \\ Institut für Allgemeine und Spezielle Zoologie der Justus-Liebig-Universität, Heinrich-Buff-Ring 29, \\ 6300 Giessen, F.R.G. (permanent address); Centre de l'Environnement, Antenne Museum (École \\ Pratique des Hautes Études, E.P.H.E., B.P. 1013, Papetoai, Moorea, French Polynesia; Laboratoire \\ Biologie Marine \& Malacologie, Université de Perpignan, Avenue de Villeneuve, 66025 Perpignan \\ Cedex, France
}

Keywords: Joeropsidae, Isopoda, Joeropsis, Society Islands

\begin{abstract}
The first contribution to the isopod family Joeropsidae from the Society Islands is given. All of the four species reported herein, Joeropsis gertrudae n. sp., J. minutus n. sp., J. polynesiensis n. sp., and J. salvati $n$. sp., are new to science. These species occur only at locations with more or less strong wave exposition. The affinities of polynesian Joeropsidae to the other members of Joeropsis are discussed.
\end{abstract}

\section{Zusammenfassung}

Es wird der erste Beitrag zur Isopoden-Familie Joeropsidae von den Gesellschaftsinseln gegeben. Alle vier genannten Arten, Joeropsis gertrudae n. sp., J. minutus n. sp., J. polynesiensis n. sp. und $J$. salvati $n$. sp. erwiesen sich als neu für die Wissenschaft. Es zeigte sich, daß diese Arten nur an stärker exponierten Lokalitäten auftraten. Die Beziehungen der polynesischen Joeropsidae zu den anderen Arten der Familie werden diskutiert.

\section{Introduction}

The monogeneric family Joeropsidae contains slightly over thirty species, most of them poorly described. To date we know nothing about the ecology and biology of this morphologically uniform and difficult group of marine Isopoda. Distribution of Joeropsis Koehler, 1885 ranges from temperate regions of the Northern Hemisphere to the Antarctic Peninsula (Schultz \& McCloskey, 1967: 103).

This paper reports on a collection of 131 specimens representing four species of littoral to shal- low-water Joeropsidae from Bora Bora and Moorea, Society Islands, collected by the author in February-March 1988. There has been no previous work published on this isopod family from French Polynesia. It is therefore not surprising that all of the four species available were undescribed. Because there is only one other report on Joeropsidae from tropical Pacific Islands (Hawaii, Miller, 1941: 315 ) it is impossible to discuss the origin or dispersal of the species of Joeropsidae from the Society Islands in this paper.

It should be noted that all species found in Polynesia are from locations with more or less strong wave exposition. Not a single specimen could be collected on the crest of sheltered fringing reefs like Turaapuo at Bora Bora and Tiahura at Moorea (see Galzin \& Pointier, 1985; Pirazzoli et al., 1985) where the author worked intensively.

\section{Material and methods}

Samples from French Polynesia have been obtained by hand while skin diving, or while wading in very shallow water. The substratum was collected and transported to the laboratory in plastic barrels. After storing in 5\% formalin/sea water for some hours, the material has been washed with fresh water over a $0.5 \mathrm{~mm}$ sieve and preserved in $70 \%$ ethanol.

Specimens are deposited in the Senckenberg-Museum, Frankfurt a.M., Germany (SMF), Muséum 


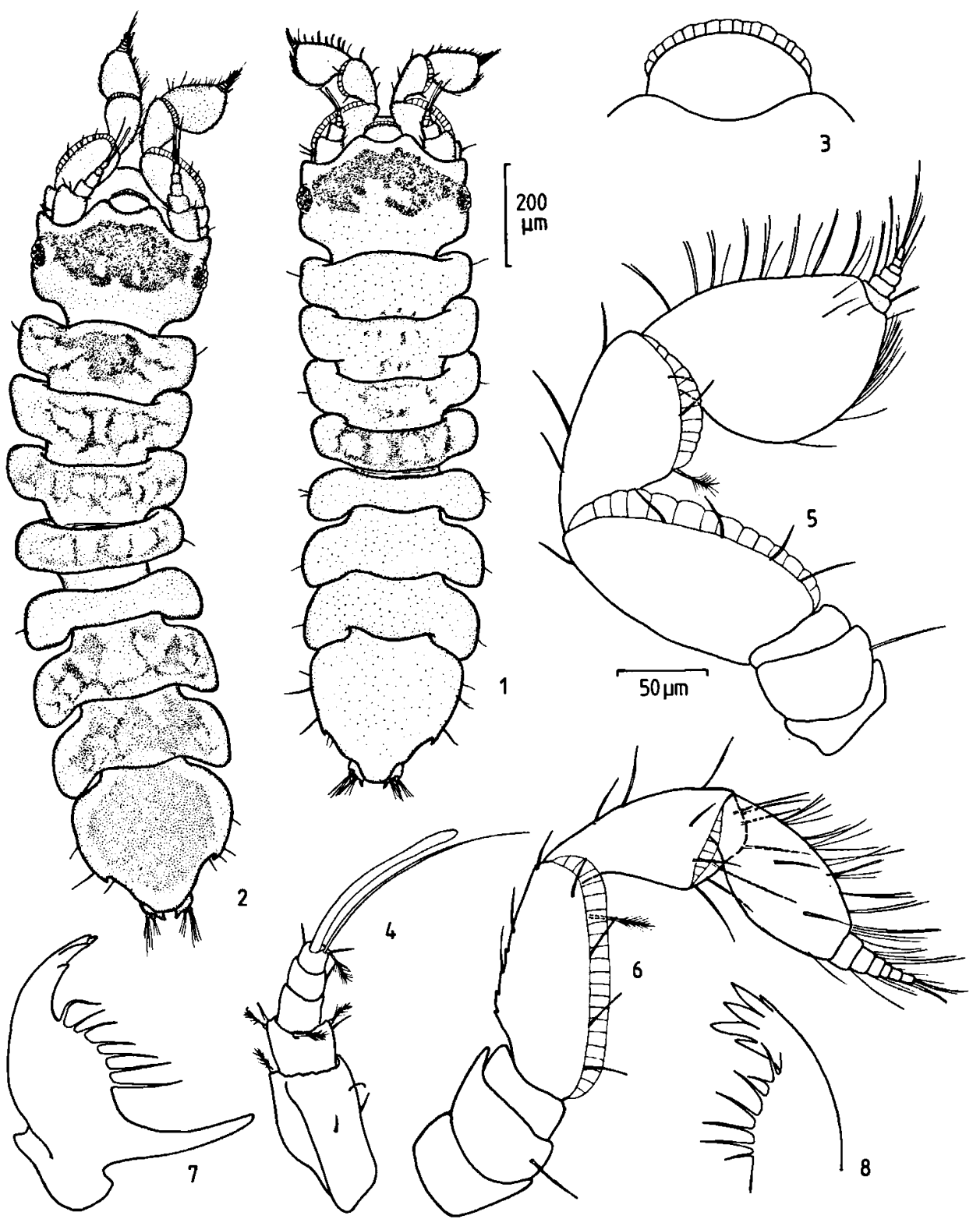

Figs. 1-8. Joeropsis gertrudae n. sp. (1,3-5, 7-8, $\sigma$ holotype; $2, \sigma$ paratype; $6, \wp$ paratype); 1 , $\sigma$ dorsal view; 2, other $\sigma$ dorsal view; 3 , rostrum; 4 , antenna $1 ; 5$, antenna $2, \sigma ; 6$, antenna 2,$8 ; 7$, left mandible, palp broken off; 8 , right mandible, palp broken off.

National d'Histoire Naturelle, Paris, France (MNHN), National Museum of Natural History, Washington, U.S.A. (USNM), Zoölogisch Museum, Amsterdam, The Netherlands (ZMA) and the Zoologisk Museum, Copenhagen (ZMC).
Joeropsis Koehler, 1885

Joeropsis gertrudae n. sp. Figs. 1-23.

Holotype. - $\sigma$ (SMF 17687), Moorea; Temae the Islet Reef, northeast of airport, dead corals near beach, about $2 \mathrm{~m}, 31$ March 1988. 


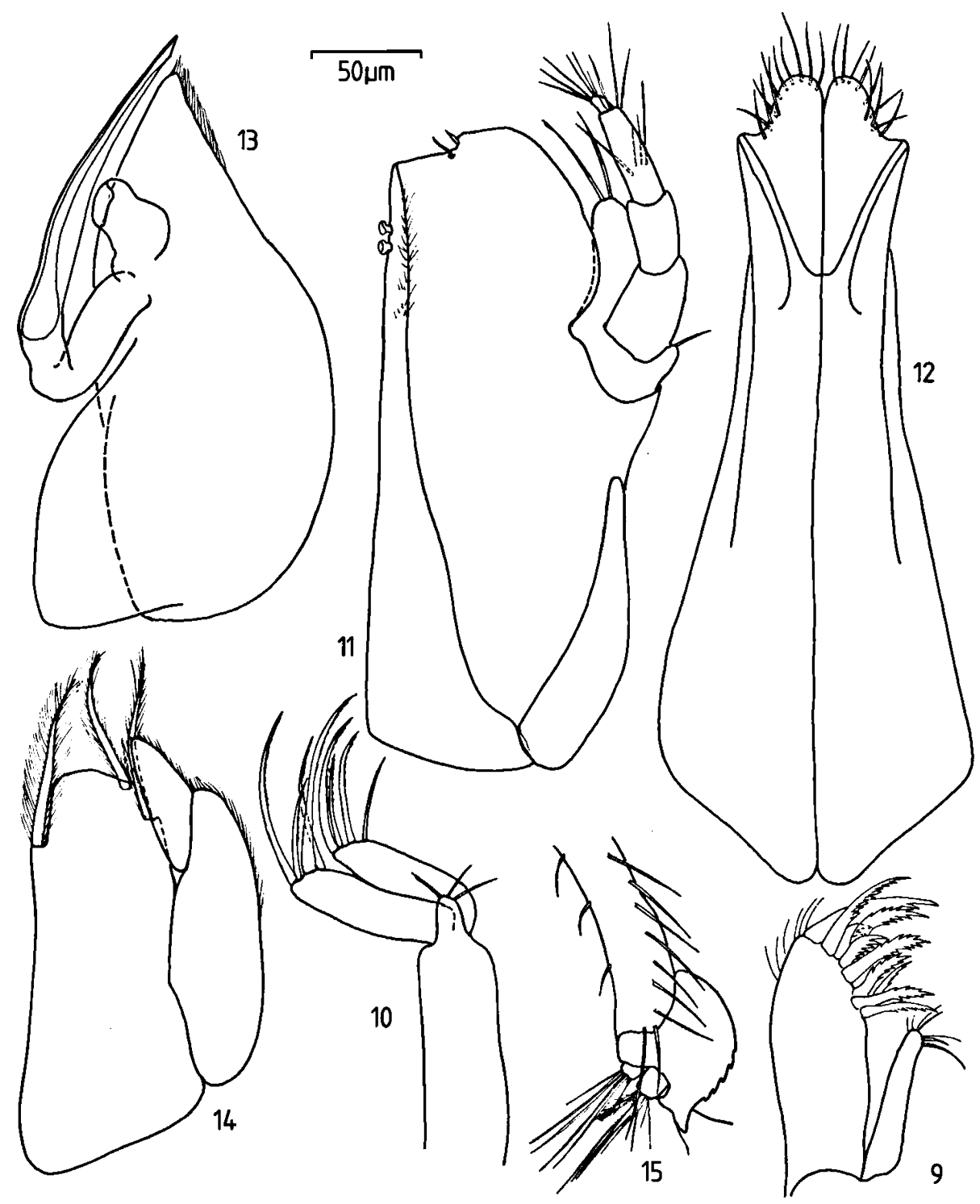

Figs. 9-15. Joeropsis gertrudae n.sp., o holotype: 9, maxilla 1; 10, maxilla 2; 11, maxilliped; 12, pleopod 1; 13, pleopod 2; 14, pleopod $3 ; 15$, uropod and ventrodistal margin of pleotelson.

Paratypes. - $1 \sigma^{\circ, 1} 1$ ( $\sigma^{\circ}$ ZMA Is. 105.383; ९ SMF 17688), Moorea; about $2.6 \mathrm{~km}$ west of airport near Maharepa, crest of barrier reef, dead corals, $0.5 \mathrm{~m}$, March 1988 .

Diagnosis. - Through the remarkable sexual dimorphism of the first flagellar segment of the second antenna this species is unique within the genus.

Description. $\sigma^{\circ}$ ○. - Total length 1.3-1.4 mm. Pigmentation variable, as figured; dorsal surface of cephalon always with broad patch of violet-brown color in distal two-thirds; dorsal surface of $\sigma$ paratype with pigment reticulation on pereonites $1-4$ and 6-7 and a large patch on pleotelson; pereonal pigment reticulation restricted to pereonite 4 and reduced to small patches on pereonites $1-3$ in $\sigma^{\circ}$ holotype. Lateral margins of head and pereonites smooth, with few short, simple setae. Cephalon 1.3 times wider than long. Lateral margins of pereo- 


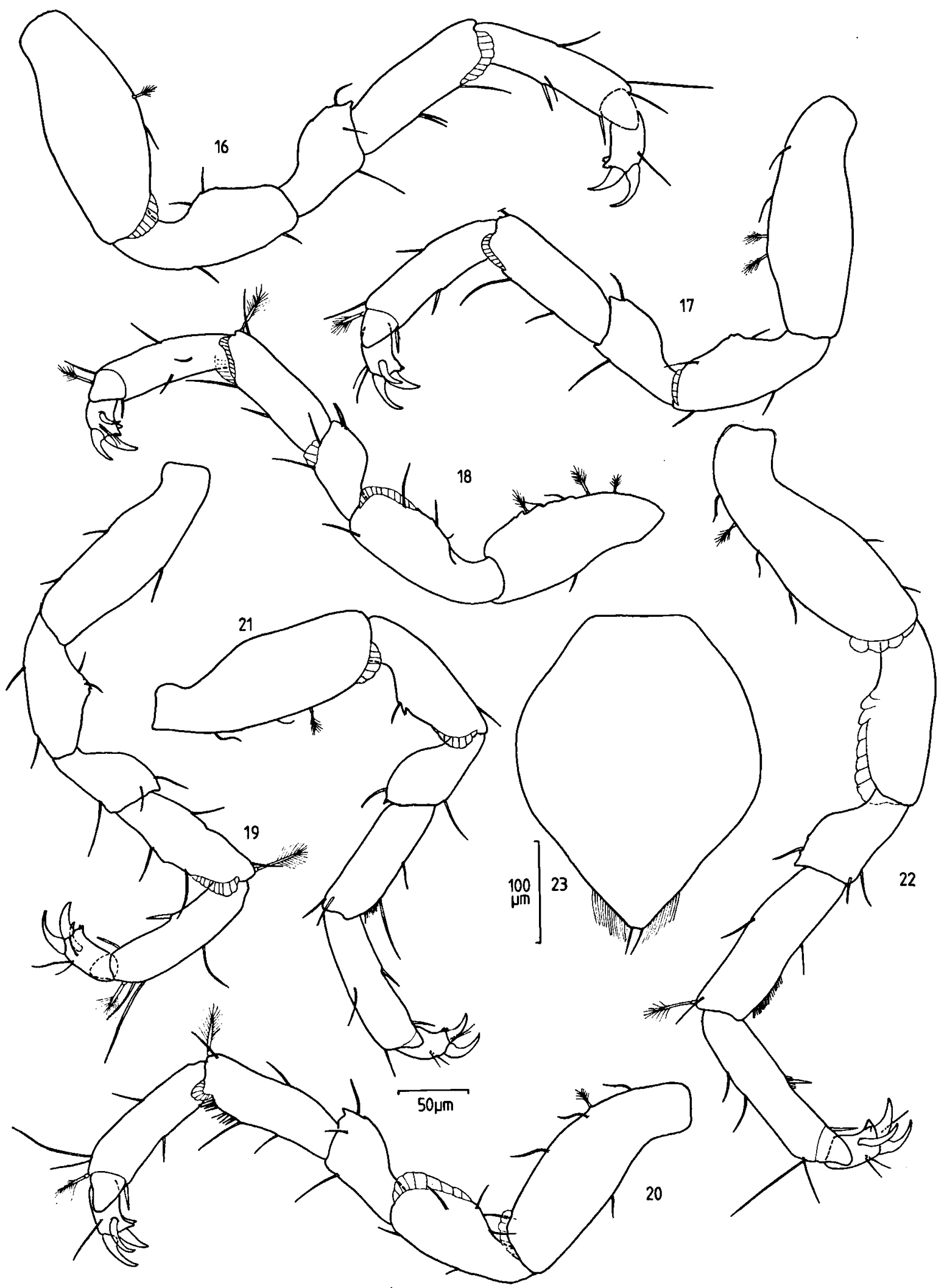

Figs. 16-23. Joeropsis gertrudae n. sp. (16-22, o holotype; 23, Q paratype): 16, pereopod 1; 17, pereopod 2; 18, pereopod 3; 19 , pereopod 4; 20, pereopod 5; 21, pereopod 6; 22, pereopod 7; 23, $९$ operculum. 


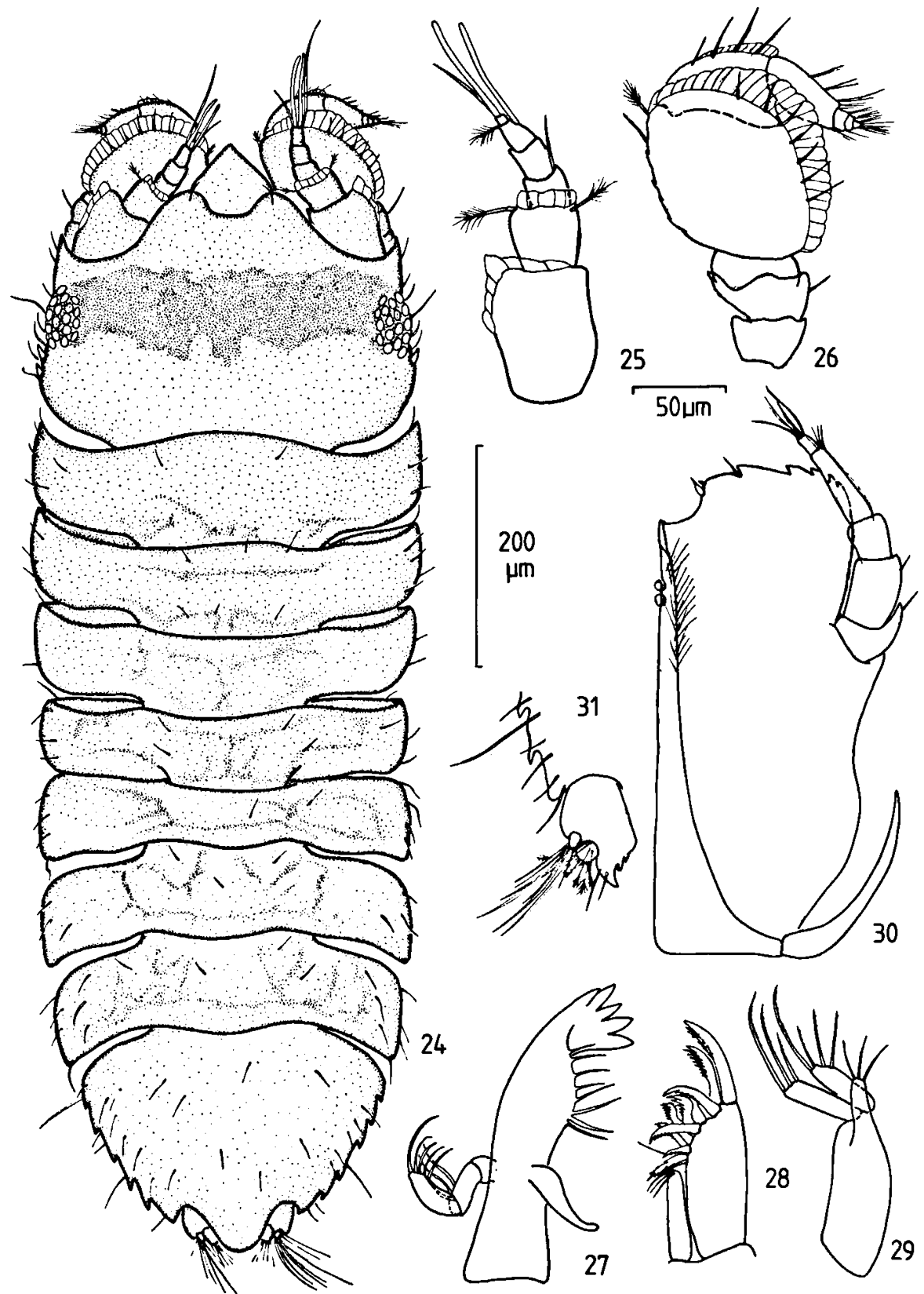

Figs. 24-31. Joeropsis minutus n. sp., o paratype: 24, dorsal view; 25, antenna 1; 26, antenna 2; 27, left mandible; 28, maxilla 1; 29, maxilla $2 ; 30$, maxilliped; 31 , uropod and ventrodistal margin of pleotelson.

nites smooth. Lateral margins of pleotelson with single tooth. Rostrum rounded, with fringe of scales. Antenna 1 of 5 segments; broad basal segment with fringe of scales, terminal segment with aesthetasc and long simple seta. Second antenna with remarkable sexual dimorphism. In both sexes peduncle of 5 segments, fourth and fifth segment with fringe of scales at ectal margin; flagellum of 5 segments with first segment greatly enlarged; this one much wider in $\sigma$ than in $\$$, at present a unique character within the genus. Mandibular palp not observed, broken off; incisor of 5 cusps; spine row 


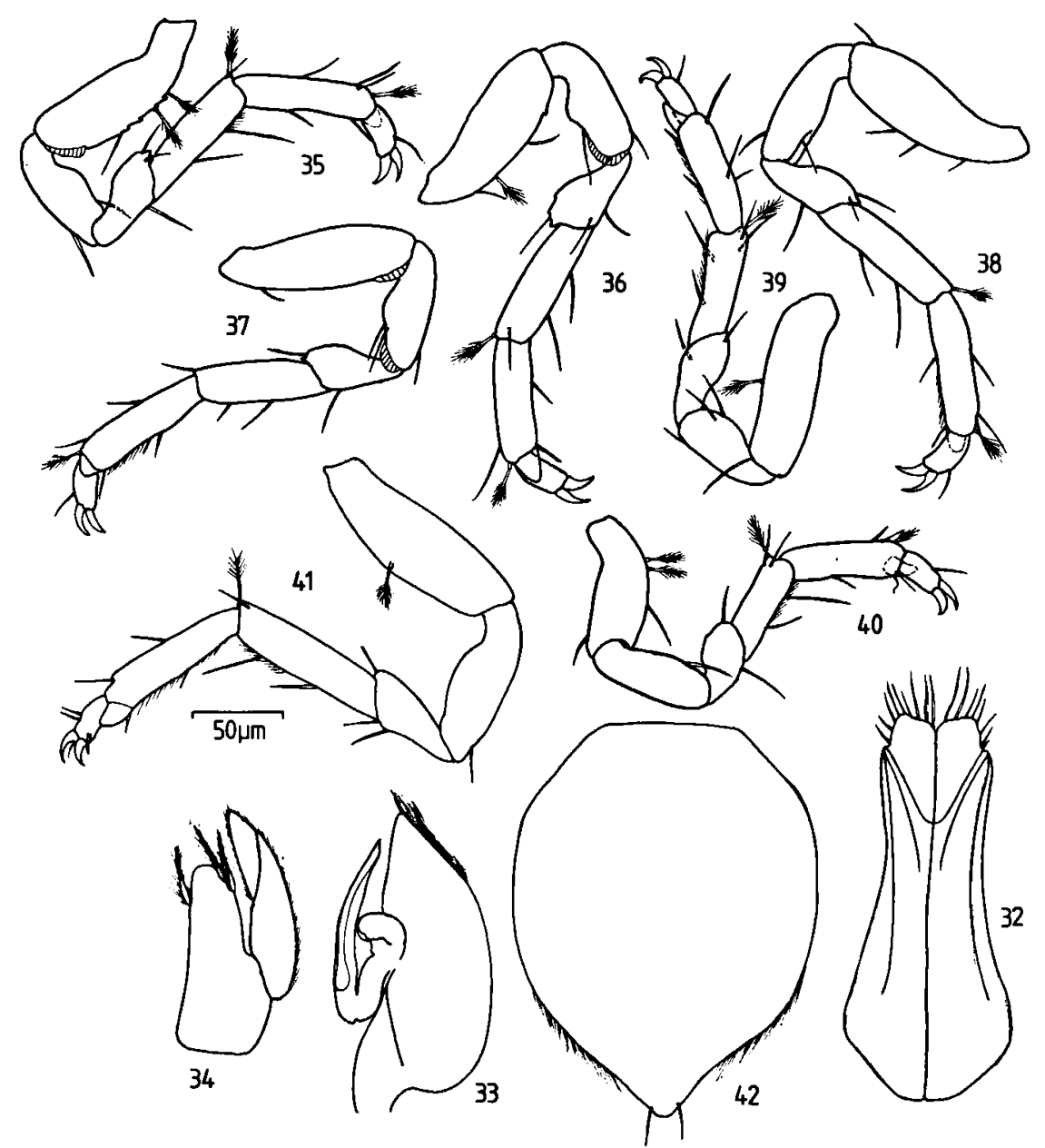

Figs. 32-42. Joeropsis minutus n. sp. (32-41, o paratype; 42, १ paratype): 32, pleopod 1; 33, pleopod 2; 34, pleopod 3; 35, pereopod $1 ; 36$, pereopod $2 ; 37$, pereopod $3 ; 38$, pereopod $4 ; 39$, pereopod $5 ; 40$, pereopod $6 ; 41$, pereopod $7 ; 42$, 9 operculum.

of both left and right mandible with 7 spines; molar elongate slender. First maxilla, outer ramus with 10 strong, serrate spines; inner ramus with 2 distal, simple setae. Maxilla 2, inner ramus much shorter than lobes of outer ramus, with 3 distal setae; inner and outer lobe of outer ramus each with four elongate spines. Maxilliped with 2 coupling hooks; palp segment 1 with mesial margin strongly lobed, segment 4 elongate, about 1.5 times length of segment 3. Pereopods as figured, ventrodistal corner of dactylus with remarkable pair of short, tooth-like processes. Pleopod $1\left(O^{\circ}\right)$ inner distal lobe setose, with 3 simple setae arising from dorsal and 7-8 simple setae from ventral surface; lateral lobe short, rounded. Pleopod 2, outer distal margin slightly concave, distal angle acute. Pleopod 3, en- dopod with 3 distal plumose setae; exopod biarticulate, outer margins setulose. Uropod with mediodistal angle flattened, triangular and acute; medial margin with 5 shallow teeth; inner ramus slightly larger than outer ramus, with variable number of feathered sensory setae and simple setae; outer ramus with simple setae only.

Operculum ( $९$ ) shield-shaped, tapering to acute apex in distal half, with fringe of fine hairs and 2 short simple setae distally.

Etymology. - Dedicated to my wife for her valuable help during the fieldwork in Polynesia.

Remarks. - J. gertrudae n. sp. can be easily distinguished from all its congeners by the remarkable 

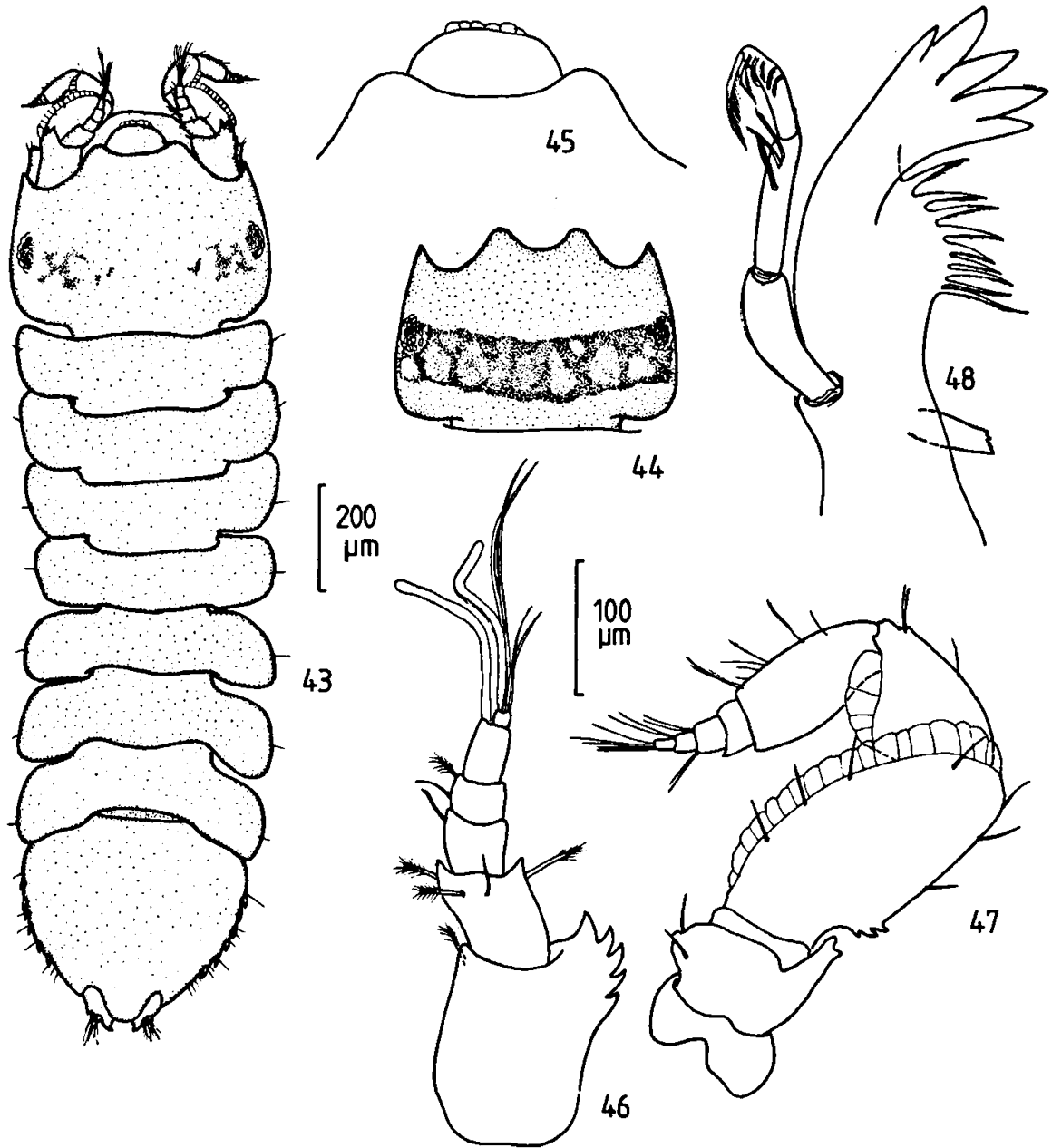

Figs. 43-48. Joeropsis polynesiensis n. sp., o paratypes: 43, dorsal view; 44, cephalon of other specimen, dorsal view; 45, rostrum; 46 , antenna $1 ; 47$, antenna $2 ; 48$, right mandible.

sexual dimorphism of the second antennae. Because of this unique character no close affinities to other species of the genus are apparent.

Distribution. - Moorea, Society Islands.

Joeropsis minutus n. sp. Figs. 24-42

Holotype. - ơ (SMF 17689), Moorea); Temae, the Islet Reef, northeast of airport, dead corals near beach, $2 \mathrm{~m}, 31$ March 1988.

Paratypes. - $7 \circ \circ, 2$ ९ (ov.), 4 immature adults (ZMA Is. 105.382) together with holotype. 10 ơ $\sigma, 7$ ९ ९ (1 ov.), 2 immature adults $\left(5 \sigma^{\circ} \sigma^{\circ}, 3\right.$ \&,, 2 immature adults SMF 17692; 2

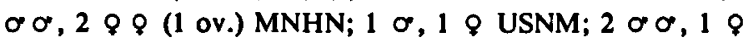
ZMC), Moorea; crest of Tiahura barrier reef, dead corals, 0.5-1 m, 25 March 1988. 1 \%, 2 \& (SMF 17691), Moorea; crest of barrier reef near Maharepa, about $2.6 \mathrm{~km}$ west of airport, dead corals, $0.5 \mathrm{~m}$, March 1988.

Diagnosis. - To date, J. minutus is the smallest member of Joeropsidae, which is, beside the shape of the first male pleopods and the greatly broadened fourth peduncular segment of the second antenna, a reliable character to distinguish it from all other species of the genus with triangular rostrum.

Description. $\sigma^{\circ}$ \&. - Total length $0.8-1.0 \mathrm{~mm}$. Head with broad transverse pigment stripe of violet-brown color and faintly reticulated pigmentation on pereonites $1-7$. Lateral margins of cephalon behind the eyes with 1-2 teeth; cephalon 1.4 


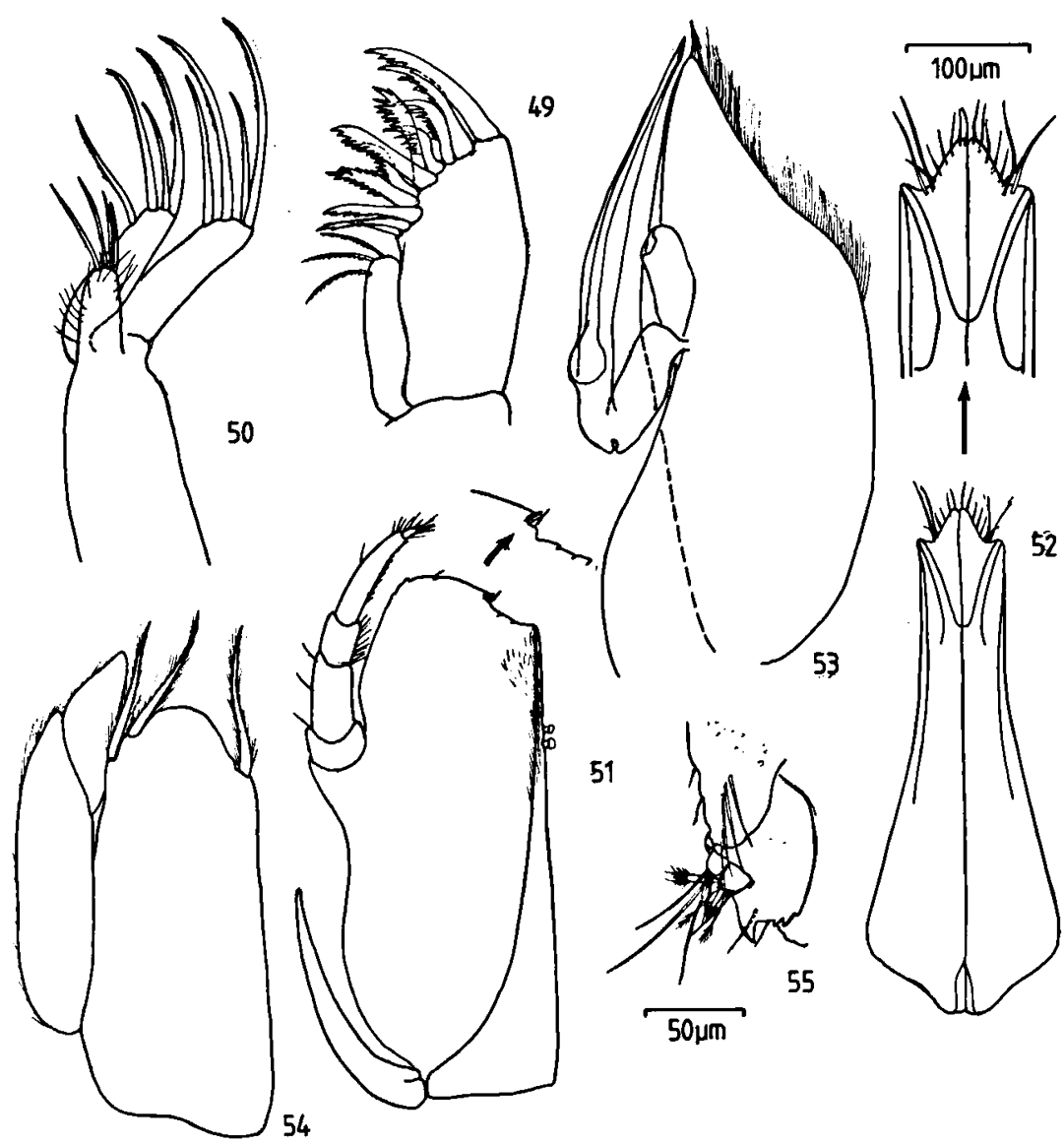

Figs. 49-55. Joeropsis polynesiensis n. sp., o paratype: 49, maxilla 1; 50, maxilla 2; 51, maxilliped; 52, pleopod 1; 53, pleopod 2; 54 pleopod 3; 55, uropod and ventrodistal margin of pleotelson.

times wider than long; lateral margins of pereonites 1-7 smooth with several short, simple setae; pleotelson laterally with 5 teeth and some short, simple setae. Rostrum triangular, acute. Antenna 1 of 6 segments, first and second widest with fringe of scales on ectal and distal margin; fifth and sixth segment with aesthetasc. Antenna 2, peduncle of five segments, fourth greatly enlarged with broad fringe of scales at ectal and distal margin; flagellum of four segments, first one elongate, three times longer than distal segments together. Incisor of mandibles with 5 cusps; spine row of both left and right mandible with 8 spines; molar elongate slender; palp of three segments, penultimate and terminal segment with 3 and 5 setae, respectively. First maxilla, outer ramus with 10 strong serrate spines; inner ramus with 3 distal, simple setae.
Maxilla 2, inner ramus about half the length of lobes of outer ramus, with 3 distal setae; inner lobe of outer ramus with 4 , outer lobe with 3 distal spines. Maxilliped, ectal margin of palp segment 1 strongly lobed, segment 4 elongate, slightly more than twice the length of segment 3 , inner part of distal margin of endite markedly concave; mediodistal margin of endite with 5 teeth, 1 simple and 2 leaflike spines; inner margin with 2 coupling hooks. Pereopods as figured. Pleopod $1\left(0^{\circ}\right)$, inner distal lobe setose, with 8-9 simple setae of variable length; lateral lobe faintly developed, rounded. Pleopod 2, outer distal margin slightly concave, distal angle acute. Pleopod 3, endopod with 3 distal plumose setae; exopod biarticulate, outer margins setulose. Uropod with mediodistal angle flattened, triangular, acute and provided with 2 shallow teeth; 
inner ramus larger than outer ramus, with variable number of feathered sensory and simple setae; outer ramus with simple setae only.

Operculum ( $\%$ ) shield-shaped, tapering to acute apex in distal third with slightly concave margins and fringe of fine hairs; 2 short simple setae subterminally.

Etymology. - The specific name refers to the very small size of the species.

Remarks. - $J$. minutus n. sp. seems to be more closely related to $J$. mediterranea Amar, 1961 from the Mediterranean, J. personatus Kensley, 1984 from Belize and $J$. indermedius Nordenstam, 1933 from the Antarctic (see Amar, 1961: 121, Kensley, 1984: 70 and Menzies \& Schultz, 1967: 174), which are all similar in their habitus, in having a triangular rostrum, and the lateral margins of head and pleotelson dentate. However, J. minutus can be easily distinguished by its minute size, the strongly widened fourth peduncular segment of antenna 2 and the shape of the first male pleopods.

Distribution. - Moorea, Society Islands.

Joeropsis polynesiensis n. sp. Figs. 43-63.

Holotype. - $\sigma$ (SMF 17693), Moorea; Temae, the Islet Reef, northeast of airport, dead corals near beach, $2 \mathrm{~m}, 31 \mathrm{March}$ 1988.

Paratypes. - 6 ९ \&, 2 \% $\circ$ (ov.), 7 immature adults (SMF 17694), together with holotype. $13 \circ \sigma, 6$ \% $(1 \mathrm{ov}),. 13 \mathrm{im}-$ mature adults (ZMA Is. 105.385), Moorea; crest of Tiahura barrier reef, dead corals, 0.5-1 m, 25 March 1988. $11 \sigma^{\circ} \sigma^{\circ}, 5 \%$ ㅇ ( 1 ov.), 15 immature adults ( 5 \% $\sigma^{\circ}, 2$ ९ ( 1 ov.) MNHN; 5 $\sigma^{\circ}, 2$, 15 immature adults ZMC; $1 \%, 1$ USNM), Moorea; slope of fringing reef near Afareaitu, dead corals, 1-2 m, 26 March 1988. 17 o o , 4 \& (1 ov.), 15 immature adults (SMF 17695), Moorea; crest of barrier reef near Maharepa, dead corals, about $0.5 \mathrm{~m}$, March 1988. $2 \sigma^{\circ} \sigma, 3$ immature adults (SMF 17696), Bora Bora; fringing reef near Vaitape, near slope, dead corals, 0.5-1 m, 27 February-6 March 1988.

Diagnosis. - Characterized in having a broad transverse pigment band in the proximal half of the cephalon (which may be reduced in some specimens), the lateral margins of the cephalon smooth, those of the pleotelson dentate, and through the shape of the antennae and first male pleopods.

Description. $\sigma^{\circ}$ ९. - Total length 1.2-2.0 mm. Broad transverse pigment band of violet-brown color in proximal half of cephalon, reduced to small patches in some specimens. Lateral margins of head and pereonites smooth, those of pleotelson with 6 teeth and some short simple setae. Cephalon 1.4 times wider than long; rostrum broadly rounded with shallow fringe of scales distally. Antenna 1 of 5 segments, with first segment largest, having 5 sharp teeth at outer distal margin; penultimate and terminal segments with aesthetasc. Antenna 2, peduncle of 5 segments; fourth segment largest, with fringe of scales at ectal and distal margin, also with 3 teeth in basal half of inner margin; second segment with elongate bifid lobe arising from inner distal margin; flagellum of 5 segments, with first segment longer than 4 distal segments together. Incisor of mandibles with 5 cusps, spine row of both left and right mandible of 9 spines; molar elongate, slender, palp of 3 segments with 3 spines at penultimate and 6 spines at terminal segment. Maxilla 1 , outer ramus with 11 strong, serrate spines; inner ramus with 3 apical setae. Maxilla 2, inner ramus about half the length of lobes of outer ramus, with 4 distal setae; inner and outer lobes of outer ramus with 4 apical spines. Maxilliped, inner part of distal margin of endite slightly concave, with 1 simple and 2 small leaflike spines; medial margin with 2 coupling hooks; 5-segmented palp with fourth segment longest. Pereopods 1-7 as figured, ischium of sixth and basis of seventh pereopod dorsally toothed.

on pleopods 1 , inner distal lobe triangular, longer than wide, with 2 long simple setae arising from dorsal margin and 5-6 shorter simple setae arising from ventral margin; lateral lobe very short, rounded. Pleopod 2, outer distal margin of exopod with fringe of fine hairs. Pleopod 3, endopod with 3 plumose setae, exopod of 2 segments with setulose outer margins. Uropodal basal segment with distal angle flattened, triangular and acute; inner margin with 3 shallow teeth; inner ramus slightly longer than outer ramus, with variable number of feathered sensory setae and simple setae; outer ramus with simple setae only. 


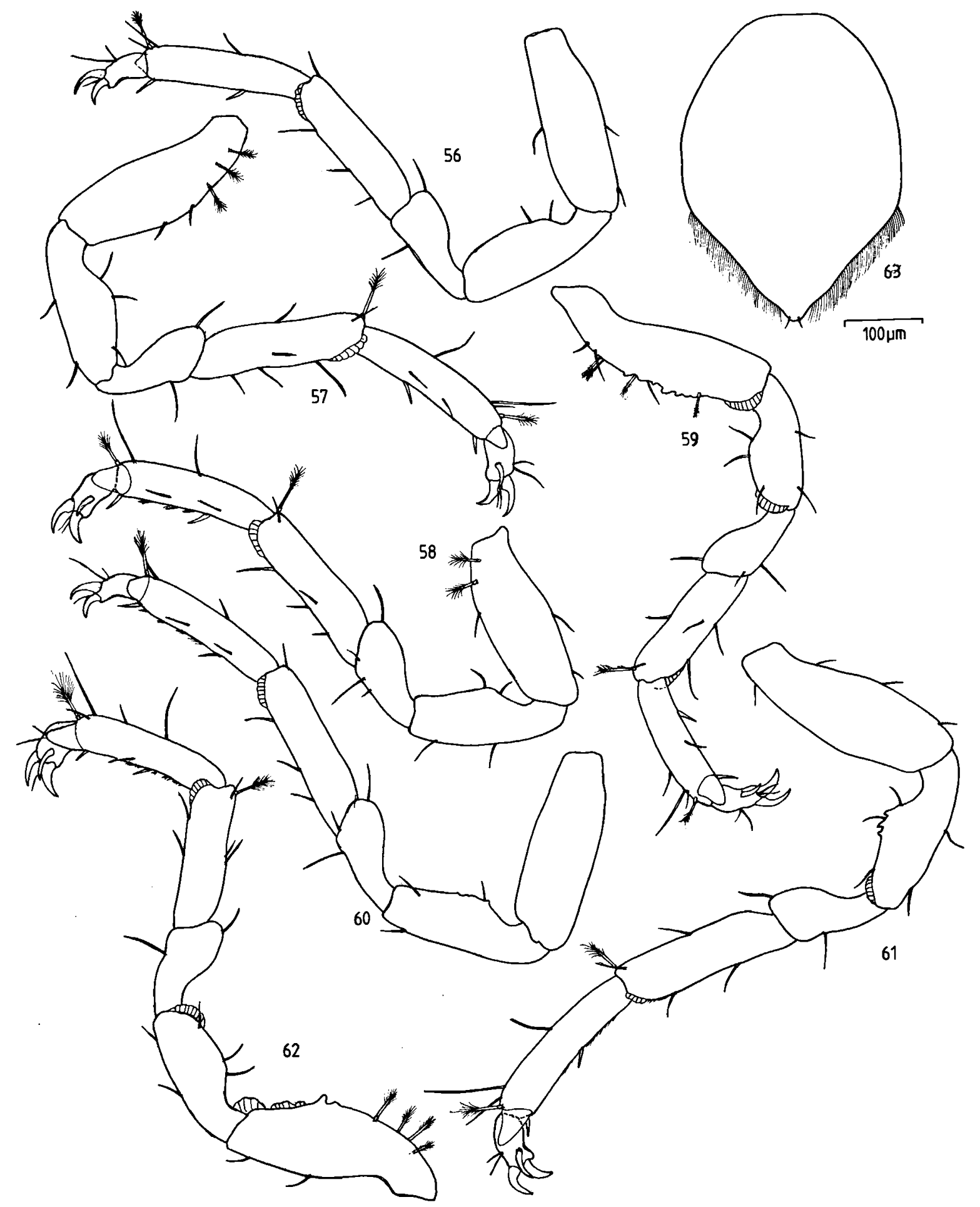

Figs. 56-63. Joeropsis polynesiensis n. sp. (56-62, or paratype; 63, \& paratype): 56, pereopod 1; 57, pereopod 2; 58, pereopod 3; 59, pereopod $4 ; 60$, pereopod $5 ; 61$, pereopod $6 ; 62$, pereopod $7 ; 63$, $९$ operculum. 


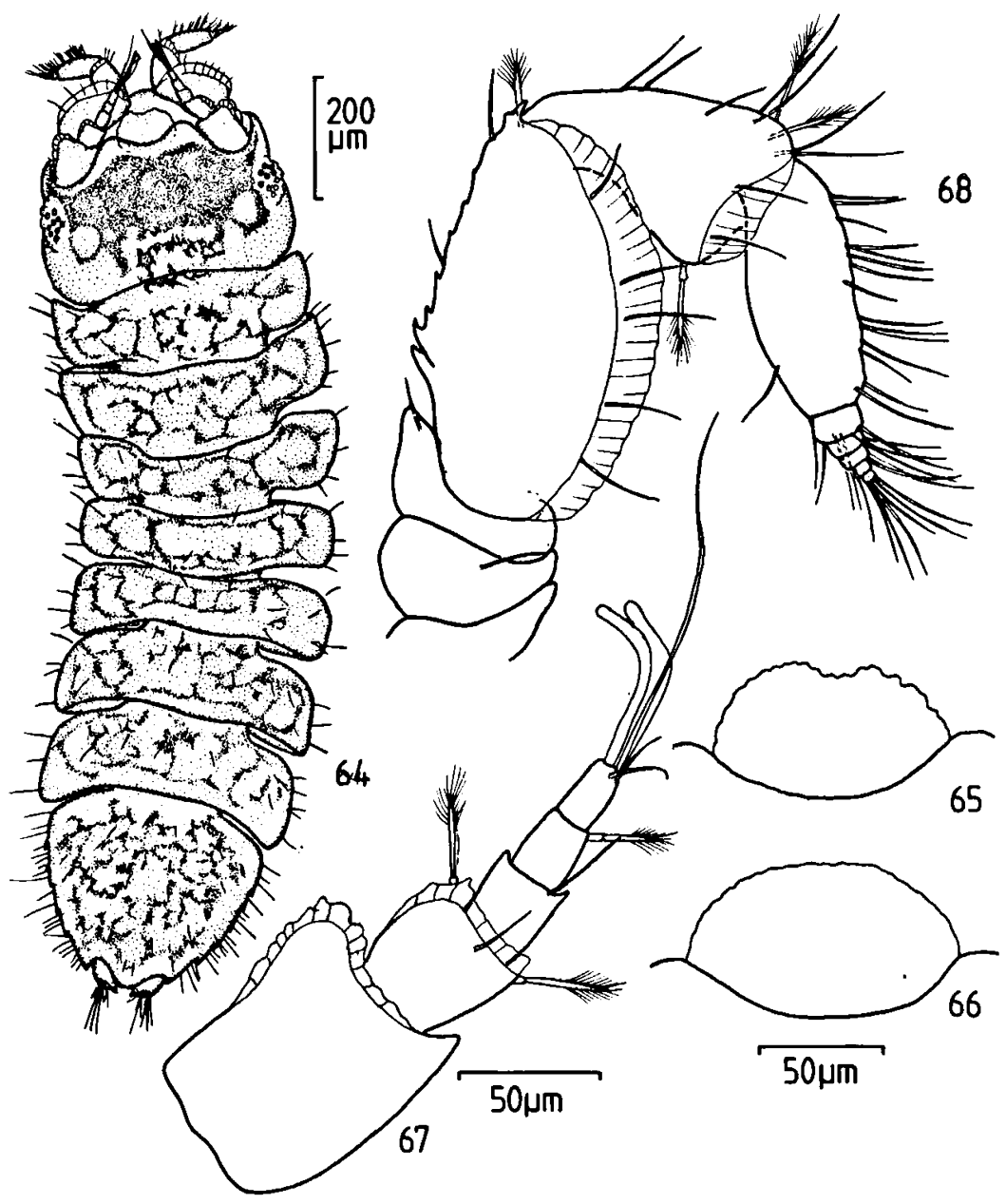

Figs. 64-68. Joeropsis salvati n. sp. (64-65, o holotype; 66, o paratype): 64, dorsal view; 65, rostrum; 66, rostrum, other specimen 67 , antenna $1 ; 68$, antenna 2.

Operculum ( $\%$ ) elongate shield-shaped, tapering to acute apex in distal third; margins of that part with fringe of fine hairs, apically with 2 short simple setae.

Etymology. - Named after the area of the type locality, French Polynesia.

Remarks. - J. polynesiensis seems to be more closely related to $J$. dubia Menzies, 1951 from California and Mexico (Menzies, 1951: 147; 1962: 339). The distinguishing characters of both species are as follows: $J$. polynesiensis: head with pigment stripe across proximal half of cephalon; basal seg- ment of antenna 1 with 5 sharp teeth at outer distal margin; inner lobe of first male pleopod longer than wide. J. dubia: broad pigment patch covering nearly whole medial surface of head; outer distal margin of first peduncular segment of antenna 1 with fringe of scales; inner lobe of first male pleopods as long as wide or slightly wider than long.

Distribution. - Bora Bora and Moorea, Society Islands.

Joeropsis salvati n. sp. Figs. 64-86.

Holotype. - $\sigma$ (SMF 17697), Moorea; slope of fringing reef near Afareaitu, dead corals, 1-2 m, 26 March 1988. 


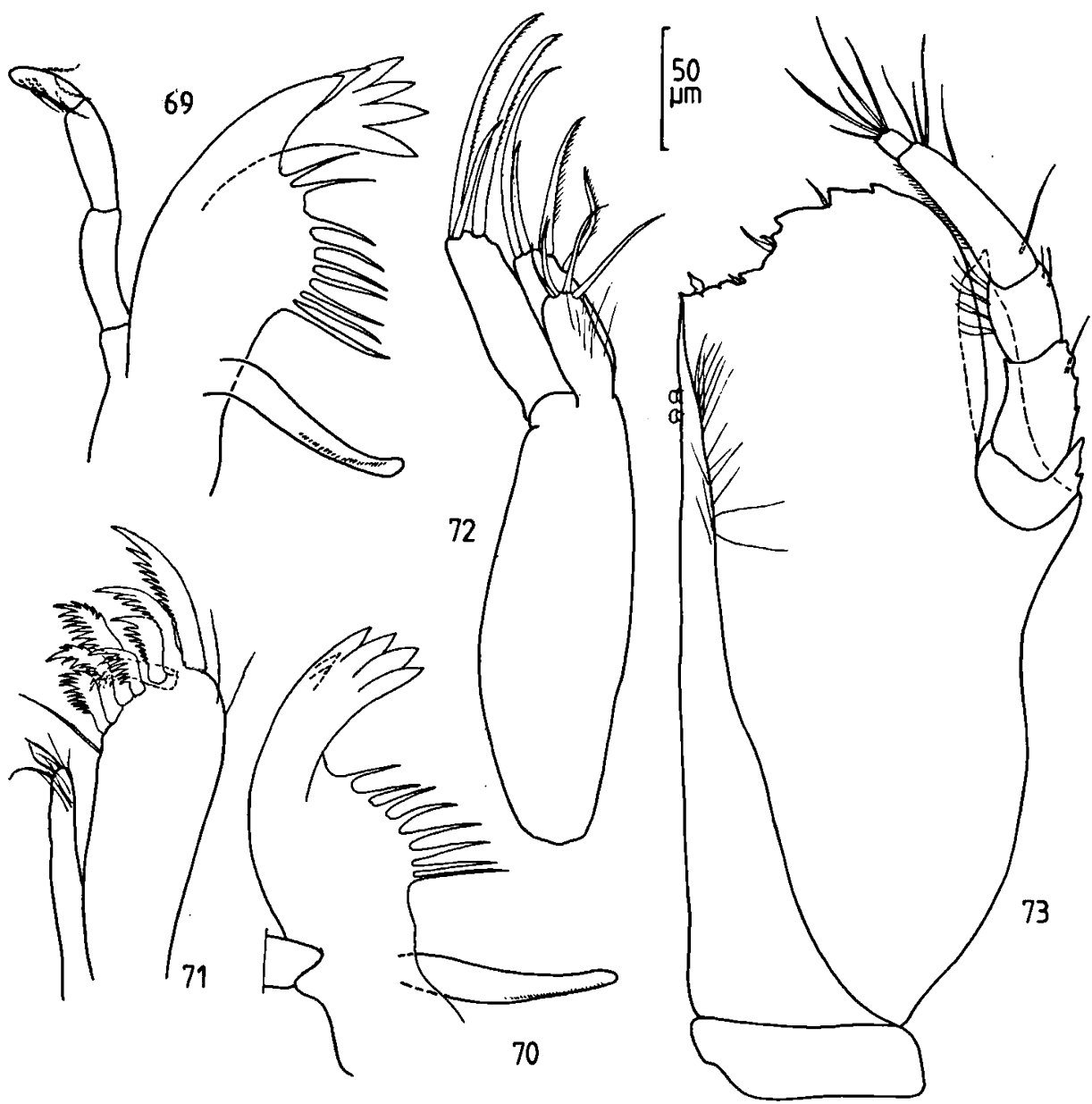

Figs. 69-73. Joeropsis salvati $\mathrm{n}$. sp., $\sigma$ holotype: 69 , left mandible; 70, right mandible, palp omitted; 71, maxilla 1; 72, maxilla $2 ; 73$ maxilliped.

Paratypes. - 4 o $\sigma^{\circ}, 3$ \% ᄋ (2 ov.), 2 immature adults $\left(1 \sigma^{\circ}\right.$, 2 immature adults SMF 17690; 1 o , 1 ov. $\odot$ MNHN; 1 o , 1 ov. \& ZMA Is.105.384; $1 \propto, 1 \% \mathrm{ZMC})$, together with holotype. $\$$ (SMF 17698), crest of Tiahura barrier reef, dead corals, 0.5-1 m, 25 March 1988.

Diagnosis. - Characterized through the following features in combination: Smooth lateral margins of cephalon and dentate lateral margins of pleotelson, pigmentation, shape of antennae 1 and 2 , as well as shape of the first male pleopods and female operculum.

Description. $\sigma$ \%. - Total length 1.0-1.5 mm. Posterior half of cephalon with broad transverse stripe of violet-brown color; anterior half of cepha- lon, pereonites 1-7 and pleotelson with pigment reticulation. Lateral margins of cephalon smooth, like lateral margins of pereonites; lateral margins of pleotelson with 5-6 teeth; pereonites and pleotelson with several short, simple setae. Rostrum broadly rounded or apically shallowly notched. Antenna 1 of 5 segments, basal segment largest; ectal and distal margin of first and second segments with fringe of scales, terminal segment with 2 aesthetascs, 1 very long and 2 short simple setae. Antenna 2, peduncle of 5 segments; fourth longest and widest, inner margin toothed; ectal and distal margin with broad fringe of scales, as well as distal margin of fifth segment; flagellum of 6 segments, basal one elongate, more than twice the length of other 


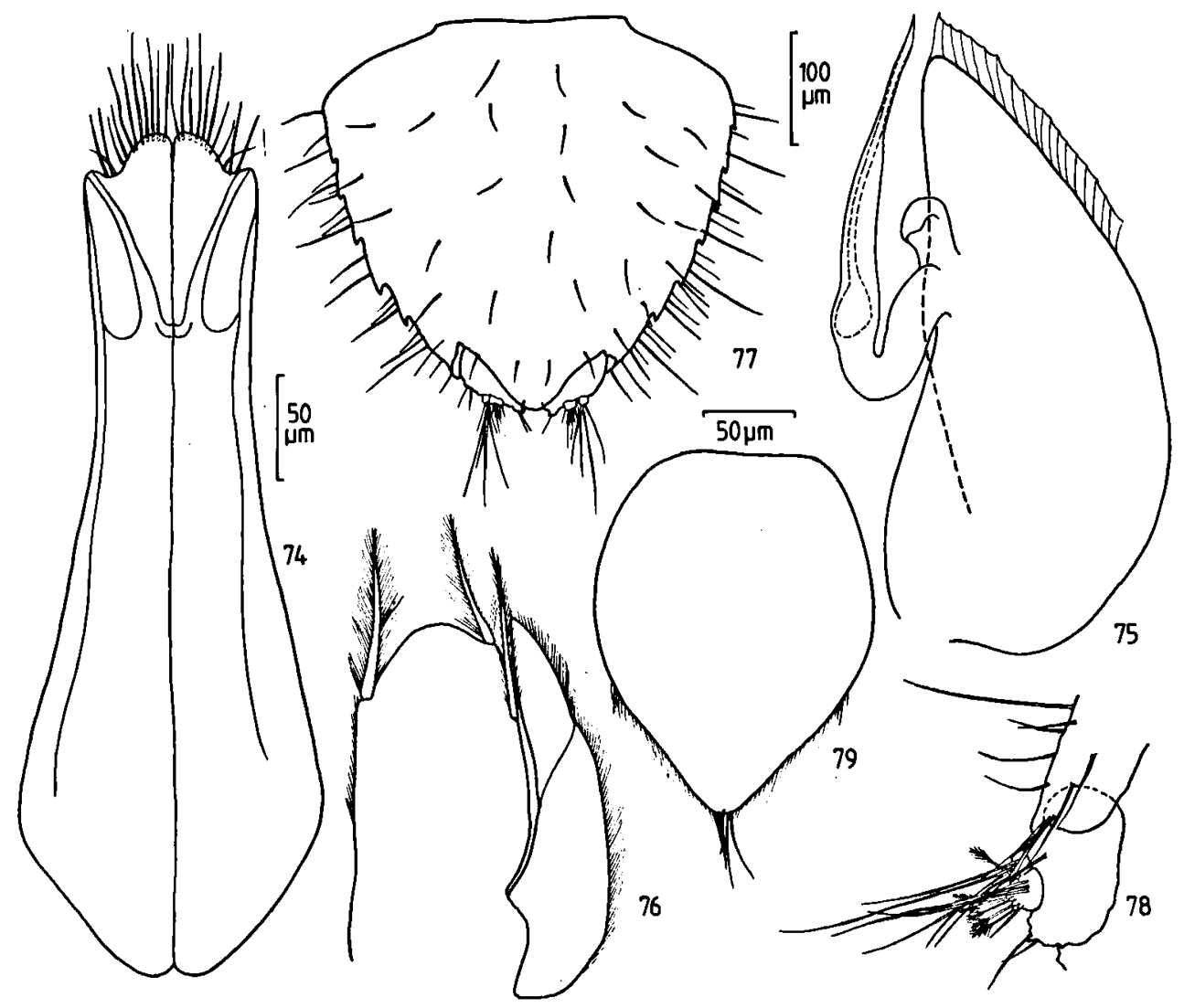

Figs. 74-79. Joeropsis salvati n. sp. (74-78, o holotype; 79, \& paratype): 74, pleopod 1; 75, pleopod 2; 76, pleopod 3; 77, pleotelson with uropods, dorsal view; 78, uropod and ventrodistal margin of pleotelson; 79, $\$$ operculum.

flagellar segments together. Incisor of mandibles with 6 cusps; spine row of left mandible of 9, of right mandible of 8 spines; molar elongate slender; terminal segment of 3-segmented palp with 6 setae. First maxilla, outer ramus with 8 strongly serrate spines, inner ramus with 3 distal setae and some fine setules. Maxilla 2, inner ramus shortest with 4 distal setae; inner and outer lobe of outer ramus each with 3 elongate spines. Maxilliped with inner part of distal margin of endite markedly concave. This part as well as mediodistal margin toothed, with 5 simple to leaflike spines; fourth segment of 5-segmented palp longest. Pereopods $1-7$ as figured, propodus, carpus, merus and ischium variously toothed.

First $\sigma$ pleopods, inner distal lobe wider than long and setose, with 2 simple setae arising from dorsal and 9-10 simple setae arising from ventral margin; lateral lobe short, rounded. Pleopod 2, outer distal margin of exopod with fringe of scales. Pleopod 3, endopod with 3 plumose setae, exopod of 2 articles with setulose outer margins. Inner distal angle of uropodal basal segment with irregular margin; inner ramus twice length of outer ramus, bearing feathered sensory setae and simple setae; outer ramus with simple setae only.

Operculum ( $\%$ ) elongate shield-shaped, tapering to apex with 5 simple setae in distal half, this part also with fringe of fine hairs.

Etymology. - Dedicated to Dr. Bernard Salvat, who made it possible for me to use the facilities of the marine biological station in Perpignan and Moorea.

Remarks. - I hesitate to describe this species as new to science because of its very close similarity to 


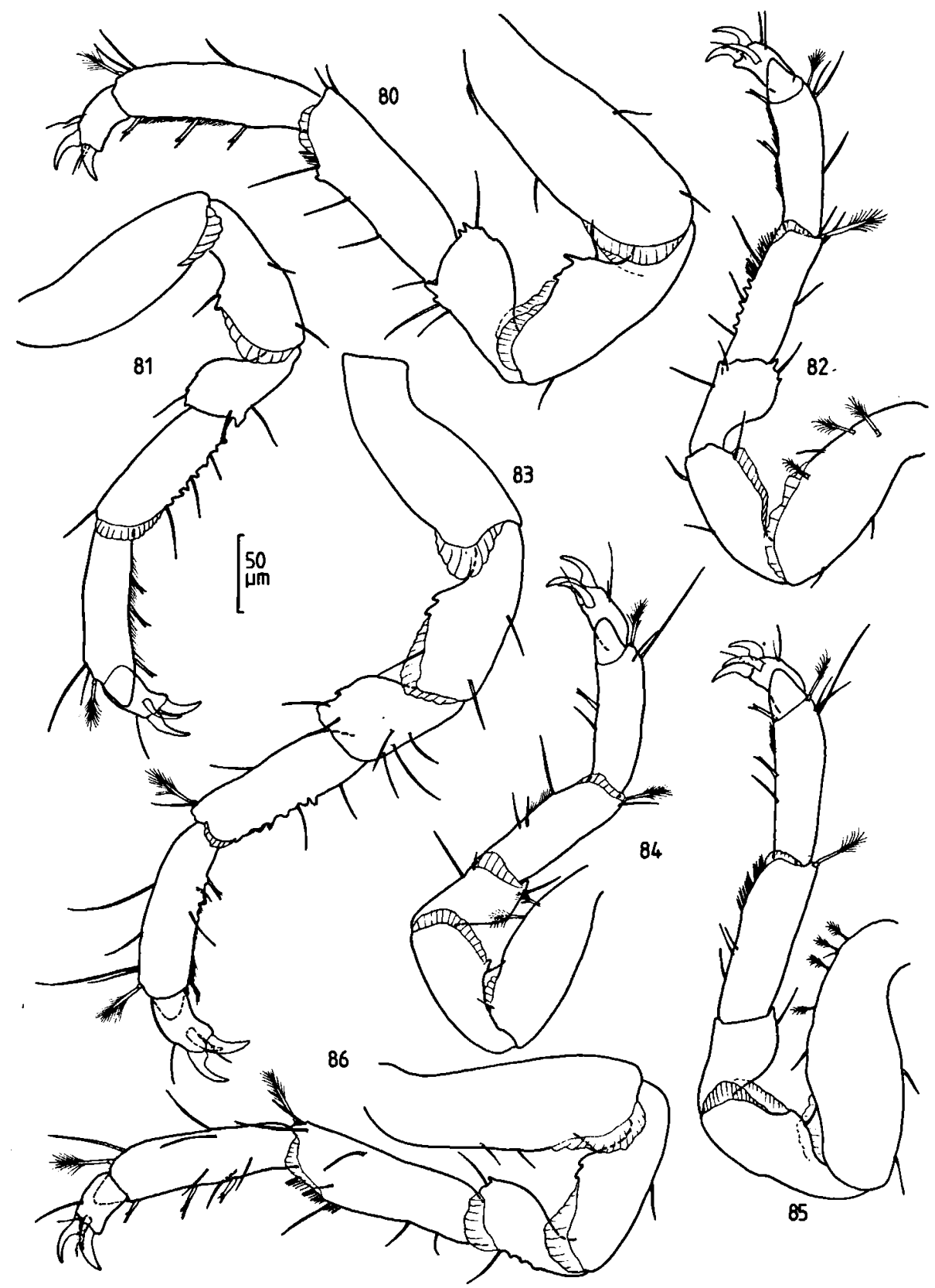

Figs. 80-86. Joeropsis salvati n. sp., $\sigma^{\circ}$ holotype: 80, pereopod 1; 81, pereopod 2; 82, pereopod 3; 83, pereopod 4; 84, pereopod 5; 85, pereopod 6; 86, pereopod 7.

Joeropsis rathbunae Richardson, 1902 from the western Atlantic. However, based on specimens collected in northern Colombia by the author (Müller, in press) and an additional description of rathbunae by Kensley (1984: 73), the following differences could be found, leading me to the presumption that $J$. salvati and $J$. rathbunae are sibling species: The inner distal lobe of the first male pleopod is wider than long in $J$. salvati, whereas it is longer than wide in $J$. rathbunae. This seems to 
be a constant character and the best feature to distinguish males of these species. The inner distal margin of the uropodal basal segment bears some teeth in $J$. rathbunae, in $J$. salvati these teeth could not be found. Females can be distinguished through the shape of the operculum which is more slender in $J$. salvati. There may be also relationships to $J$. coralicola Schultz \& McCloskey, 1967 from the western Atlantic, from which it may be distinguished through the dentate inner margin of the fourth peduncular segment of antenna 2, the more robust first male pleopods and the more sparsely developed setation of the body.

Distribution. - Moorea, Society Islands.

\section{Acknowledgments}

This study was carried out at the marine biological station Antenne Museum (École Pratique des Hautes Études, E.P.H.E.) at Moorea, French Polynesia and the Laboratoire de Biologie Marine et Malacologie, Université de Perpignan, France (director: Dr. Bernard Salvat). My thanks are due to Dr. Salvat for making it possible to use the facilities of the institutes in Moorea and Perpignan, also to Dr. René Galzin, adjoint director of the Antenne Museum for organizing my field work at Moorea. Mrs. Terry McLeary kindly revised the English text. This study was partly supported through a grant of the Hessische Graduiertenförderung (HGFöN).

\section{References}

Amar, R., 1961. Jaeropsis mediterranea nov. sp. (Isopode Asellote) et les Jaeropsis mediterranéennes. Rec. Trav. St. Mar. Endoume, Bull. 23, (37): 121-129.

Galzin, R. \& J.P. Pointier, 1985. Moorea island, Society archipelago. In: B. Delesalle, R. Galzin \& B. Salvat (eds.), 5th International Coral Reef Congress, Tahiti, 27 May-1 June 1985, Vol. 1: 'French Polynesian Coral Reefs': 73-102.

Kensley, B., 1984. The Atlantic Barrier Reef ecosystem at Carrie Bow Cay, Belize, III: New marine Isopoda. Smiths. Contr. mar. Sci., 24: 1-81.

Menzies, R.J., 1951. New marine isopods, chiefly from northern California, with notes on related forms. Proc. U.S. natn. Mus., 101 (3273): 105-156.

Menzies, R.J., 1962. The marine isopod fauna of Bahia de San Quintin, Baja California, Mexico. Pac. Natural., 3 (11): 337-348.

Menzies, R.J. \& G.A. Schultz, 1967. Antarctic isopod Crustacea, II. Families Haploniscidae, Acanthaspidiidae, and Jaeropsidae, with diagnoses of new genera and species. In: G.A. Llano \& W.L. Schmitt (eds.), Biology of the Antarctic Seas, III, Antarct. Res. Ser., 11: 141-184.

Miller, M.A., 1941. The isopod Crustacea of the Hawaiian Islands, II. Asellota. Occ. Pap. Bernice P. Bishop Mus., 15 (13): 305-320.

Müller, H.-G., in press. Joeropsidae aus N.-Kolumbien, mit zwei Neubeschreibungen (Crustacea: Isopoda: Asellota). Senckenbergiana biol.

Pirazzoli, P.A. et al., 1985. Leeward islands (Maupiti, Tupai, Bora Bora, Huahine), Society archipelago. In: B. Delesalle, R. Galzin \& B. Salvat (eds.), 5th International Coral Reef Congress, Tahiti, 27 May-1 June 1985. Vol. 1: 'French Polynesian Coral Reefs': 17-72.

Schulz, G.A. \& L.R. McCloskey, 1967. Isopod crustaceans from the coral Oculina arbuscula Verrill. J. Elisha Mitchell sci. Soc., 83: 103-113.

Received: 22 October 1988

Revised: 22 February 1989 